Journal of Ocean Engineering and Technology 26(6), 74-79, December, 2012 http://dx.doi.org/10.5574/KSOE.2012.26.6.074

\author{
선체 국소 저항 수치 해석 \\ 박동우* - 서장훈** · 윤현식*** - 전호환*** - 정재환*** • 김미정**** \\ *현대중공업 선박해양연구소 \\ **삼성중공업 조선해양연구소 \\ ***부산대학교 조선해양플랜트글로벌핵심연구센터 \\ ****부산대학교 조선해양공학과
}

\title{
Numerical Analysis of Ship Local Resistance
}

\author{
Dong-Woo Park*, Jang-Hoon Seo**, Hyun-Sik Yoon***, Ho-Hwan Chun***, \\ Jae-Hwan Jung ${ }^{* * * *}$ and Mi-Jeong Kim ${ }^{* * * *}$ \\ *Maritime Research Institute, Hyundai Heavy Industries Co. Ltd., Ulsan, Korea \\ ${ }^{*}$ Marine Research Institute, Samsung Heavy Industry Co. Ltd., Geoje, Korea \\ ${ }^{* * *}$ Global Core Research Center for Ships and Offshore Plants, Pusan National University, Busan, Korea \\ ****Department of Naval Architecture and Ocean Engineering, Pusan National University, Busan, Korea
}

KEY WORDS: Flow characteristics 유동특성, Local flow 국부 유동, Drag Coefficient 항력계수, SVM 스테이션-수직 섹션 맵

ABSTRACT: The present study aims at suggesting the systematic approach to analyze the local drag components as the resistance performance characterized by the flow of the ship. In order to identify the local areas, the hull surface is decomposed into SVM (Station-Vertical Section Map) which consists of 20 stations along the longitudinal direction and 20 sections along the vertical direction (from the bottom to the waterline). Successively, on the SVM, the friction and pressure drag coefficients as the components of total drag coefficient have been analyzed for two different hull forms of Wigley and KVLCC by using CFD.

\section{1. 서 론}

선박의 고속화와 대형화 및 고유가 시대에 필수요건인 에너 지 절감형 선형의 개발 시 선체 표면의 국부 영역에서 저항값 들의 정성 및 정량적인 변화의 보다 세밀한 분석은 불가피하다 고 판단되어진다.

하지만, 기존의 실험 및 전산해석 방법들을 사용하여 선체의 저항성능 등을 해석한 연구들은 국부 저항값들의 평가보다는 전체 선형의 총저항 관점에서 해석의 초점을 맞추어 왔다. 대표 적인 선행연구로 Kim et al.(1999)은 풍동실험을 통해 선체 선미 부의 국부 유동 해석 및 난류의 특성값들에 대한 연구를 수행 하였다. Lee et al.(2003)은 모형선 스테이션(Station)별 국부 유 동을 풍동실험을 통해 해석하였다. 전산해석방법을 사용한 연 구로서는 Kim et al.(2000)은 포텐셜유동을 고려하여 선체 조파 저항의 성능을 해석하였고, 반면, Park et al.(2004)은 자유수면 을 고려한 점성유동 해석을 통하여 선체 주위의 파형과 선체 저 항성능에 대한 연구를 수행한 바 있다.
따라서, 본 연구에서는, 선체의 저항성능 해석 시 보다 체계 적이고 표준화될 수 있는 분석방법으로, 선체를 길이 방향으로 는 기존의 Station $\left(S_{T}\right)$ 으로 분할하고, 추가적으로 흘수방향으로는 Vertical section $\left(V_{S C}\right)$ 으로 분할하여 형성된 $S_{T}$ 와 $V_{S C}$ 를 두 축으 로 하는 2차원 정사각형 평면(SVM, Station-vertical section map) 에 선체 국소 저항값들을 나타내어, 선수에서부터 선미까지 또한 선저에서부터 흘수까지 모든 선체 표면에서의 이러한 값들을 단일 그림 상에서 한눈에 파악할 수 있는 새로운 방법을 제시 하고자 한다. 또한, 이를 통해, 선체표면을 따라 생성된 격자계를 사용하여 표준화된 위치 또는 영역을 정의하기는 매우 어렵다 는 단점을 극복할 수가 있다. 제시된 SVM을 활용하여 두가지 선형인 Wigley선형과 KVLCC선형의 국부 영역에서 저항값들을 본 연구에서 분석한다.

\section{2. 수치해석 방법}

본 연구에서는 삼차원 정상상태 비압축성 점성유동을 고려하

Received 19 July 2012, revised 28 November 2012, accepted 11 December 2012

Corresponding author Hyun-Sik Yoon, +82-51-510-3685, lesmodel@pusan.ac.kr

(c) 2012, The Korean Society of Ocean Engineers 
였으며, 난류모델로는 표준 $k-\epsilon$ 모델을 사용하였다. 이에 대응 하는 지배방정식으로는 식(1)의 연속방정식과 식(2)의 RANS (Reynolds averaged navier-stokes)방정식이다.

$$
\begin{aligned}
& \frac{\partial U_{i}}{\partial x_{i}}=0 \\
& \frac{\partial}{\partial x_{j}}\left(\rho U_{i} U_{j}\right)=-\frac{\partial P}{\partial x_{i}}+\frac{\partial}{\partial x_{j}}\left[\mu\left(\frac{\partial U_{i}}{\partial x_{j}}+\frac{\partial U_{j}}{\partial x_{i}}\right)\right]+\frac{\partial}{\partial x_{j}}\left(-\rho \overline{u_{i}^{\prime} u_{j}^{\prime}}\right)
\end{aligned}
$$

여기서 $x_{i}, U_{i}, P, \rho$ 와 $\mu$ 는 직각좌표계, 속도성분들, 압력, 밀 도와 점성을 각각 나타낸다. 또한, 식(2)의 레이놀즈 응력(Reynolds stress)항인 $-\rho \overline{u_{i}^{\prime} u_{j}^{\prime}}$ 은 표준 $k-\epsilon$ 모델에 의해 결정되어진다.

유한체적법에 근거한 범용 프로그램인 Fluent(2009)을 사용하 여 위의 지배방정식을 계산하였다. 따라서 Fluent(2009)이 지원하 는 SIMPLE법을 기반으로 대류항과 확산항에는 2차 상류차분법 과 2차 중심차분법을 각각 적용하였다.

본 계산에서 고려되어진 좌표계, 계산영역 및 경계조건들은 Fig. 1에 도시되어져 있다. 그림에서 보듯이 본 연구에서는 자유수면 을 배제한 이중모형(Double model)을 고려하였다.

Table 1은 본 연구에서 고려한 두가지 선형인 Wigley선형과 KVLCC선형의 주요 제원을 보여준다.

수치해석 결과의 적합성을 검증하기 위하여, 23차 ITTC에서 추천하는 방법(Wilson et al., 2001) 에 따라 KVLCC 이중모형에 대해 Case1, Case2 및 Case3의 세가지 격자계를 고려하여 $R_{N}=4.6 \times 10^{6}$ 인 조건에서 총저항값들을 비교하였다. 세가지 격자 계는 Table 2에 나타낸 바와 같이, 격자수는 일정한 비율 $\left(r_{g}=\triangle x_{2} / \triangle x_{1}=\triangle x_{3} / \triangle x_{2}=\sqrt{2}\right)$ 로 Case1에서 Case3로 갈

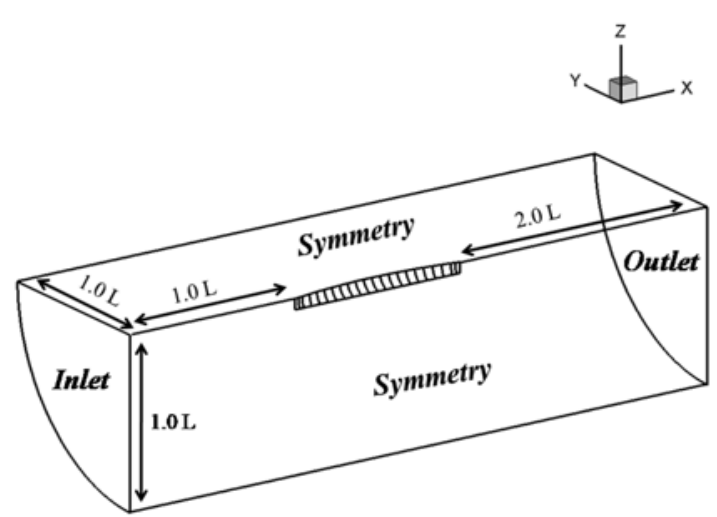

Fig. 1 A schematic diagram of the system

Table 1 Computational conditions for each hull

\begin{tabular}{ccc}
\hline \hline & Wigley & KVLCC \\
\hline$L P P(\mathrm{~m})$ & 2.5 & 5.5172 \\
$B(\mathrm{~m})$ & 0.25 & 1.0 \\
$T(\mathrm{~m})$ & 0.15625 & 0.3586 \\
$V s(\mathrm{~m} / \mathrm{s})$ & 1.565 & 1.0469 \\
$R N$ & $3.9 \times 10^{6}$ & $4.6 \times 10^{6}$ \\
$W S A\left(\mathrm{~m}^{2}\right)$ & 0.4651 & 4.1285 \\
\hline
\end{tabular}

Table 2 Grid dependence test

\begin{tabular}{cccc}
\hline \hline & Case1 & Case2 & Case3 \\
\hline No. of Grid & 316,996 & 905,850 & $2,542,504$ \\
$\mathrm{Y}+$ & 140 & 100 & 70 \\
Ymin & 0.0032 & 0.0025 & 0.0016 \\
$\mathrm{CT} \times 10^{3}$ & 4.0442 & 3.9504 & 3.9139 \\
\hline
\end{tabular}

수록 증가한다. 여기서, $\mathrm{Ymin}$ 은 선체표면과 첫번째 격자와의 평균 간격이고, $\mathrm{Y}+$ 는 $\mathrm{Ymin}$ 을 벽단위로 나타낸 값으로 벽법칙 을 만족하는 대수영역에 있다. Wilson et al.(2001)이 제안한 이 중모형에서 격자의존성 및 수치해석방법의 검증법에 본 연구에 서 고려한 세가지 격자계에서 얻은 총저항값들을 대입하였을 때, 검증조건에 부합하는 결과를 얻을 수가 있었다. 따라서, 본 연 구에서 고려한 세가지 격자계 및 수치해석 방법은 타당하다고 판단되어진다. 이에, 계산의 시간 및 효율성을 고려하여 중간격 자계인 Case2를 본 연구의 계산에 도입하였다.

\section{SVM(Station-vertical section map)정의}

Fig. 2에서는 복잡한 삼차원 선체 표면에 대응하는 $S_{T}$ 와 $V_{S C}$ 를 두 축으로 하는 2차원 정사각형 평면인 SVM을 보여준다. 여 기서, $S_{T}$ 는 선형의 길이 방향으로 20 개로 등분하여 나눈 국소영 역인 기존의 표준화된 Station을 나타내고, $V_{S C}$ 는 선저 바닥으로 부터 수선까지를 20개로 등분하여 나눈 국소영역인 Section으로 정의되어진다.

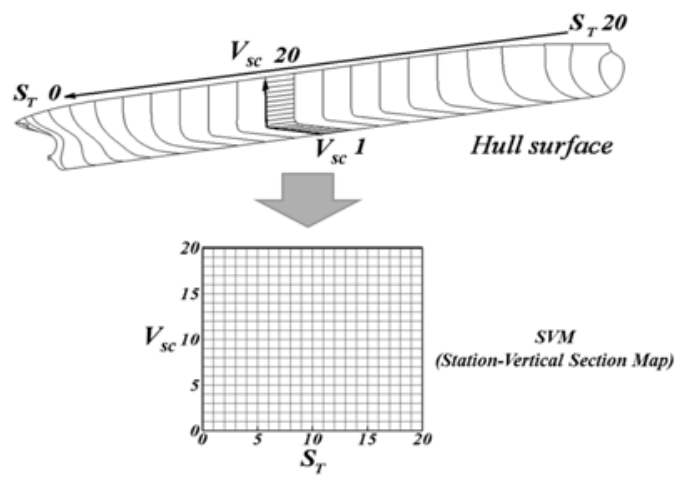

Fig. 2 Definition of SVM corresponding to the hull surface

\section{4. 결 과}

\subsection{Wigley 수학선형}

Fig. 3에 해당하는 선체 길이방향의 각 Station에 작용하는 압 력에 의한 항력계수 $\left(C_{D P}\right)$ 와 마찰에 의한 항력계수 $\left(C_{D F}\right)$ 및 이들 의 합인 총 항력계수(Total drag coefficient, $\left.C_{D}\right)$ 의 분포를 Fig.

20 St.

o St.

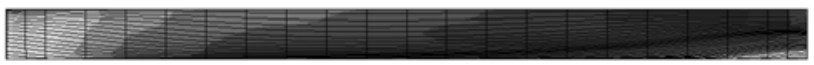

Fig. 3 Total pressure \& Wall shear limiting streamlines on the surface of Wigley 


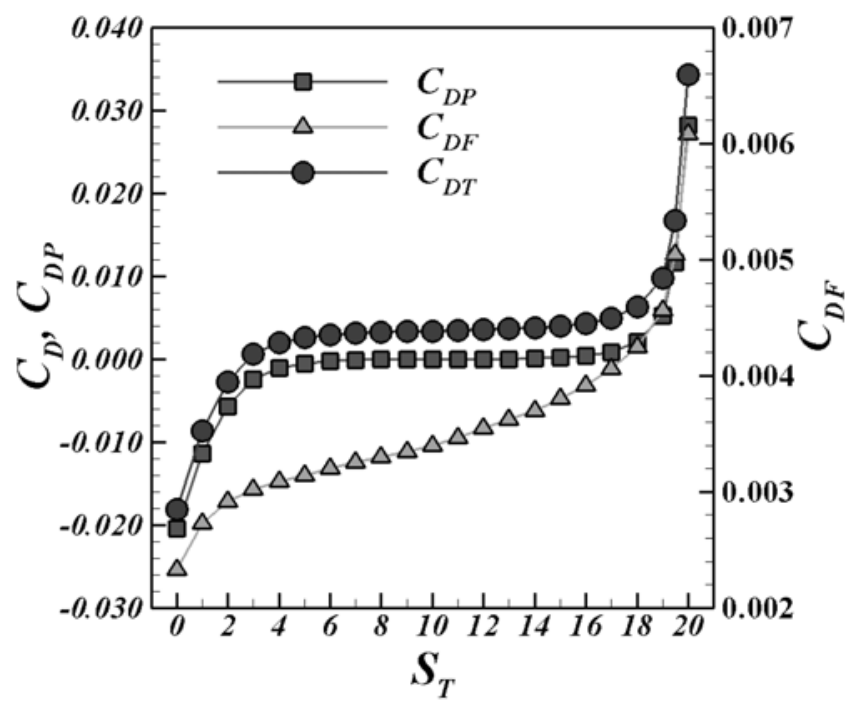

Fig. 4 Drag coefficients as $s$ function of the station $\left(S_{T}\right)$, where $C_{D}$, $\mathrm{C}_{\mathrm{DP}}$, and $\mathrm{C}_{\mathrm{DF}}$ are total, pressure and friction drag coefficients, respectively

4 에 나타내었다. 여기서, 각 저항계수들은 $0.5 \rho U_{\infty}^{2} A$ 에 의해서 무차원되어 졌으며, $U_{\infty}$ 와 $A$ 는 입구속도와 각 국소면적을 각각 의미한다.

자유유동이 가지는 운동량이 전방 정체점인 선수에서 압력으 로 거의 모두 변환되므로 선수를 포함하는 $S_{T}=20$ 에서 $C_{D F}$ 는 양의 최대값을 가진 후 선수부 근처의 곡면 $\left(18 \leq S_{T} \leq 20\right)$ 을 지나 면서 $C_{D P}$ 는 급격히 감소한 후 유동의 지배적인 속도성분인 길 이방향 속도와 선형이 평행 한 평행부 $\left(4 \leq S_{T} \leq 17\right)$ 에서 거의 ‘ 0 ’이 된다.

선미 근처의 곡면 영역 $\left(0 \leq S_{T}<4\right)$ 에서는, 법선방향 속도성 분의 영향을 받기 시작함으로 $C_{D P}$ 는 음의 값을 가지면서 다시 급격히 증가하여 선미를 포함하는 $S_{T}=0$ 에서 음의 최대값을 가 진다.

$C_{D F}$ 는 유체가 전방 정체점인 선수를 지나 곡면을 따라 가속 되면서 전단력이 증가되는 선수 $\left(S_{T}=20\right)$ 에서 최대값을 가진 후 $S_{T}$ 가 증가할수록 계속 감소하는 것을 Fig. 4에서 확인할 수가 있다. 하지만, $S_{T}$ 에 따른 $C_{D F}$ 의 감소율은 영역에 따라 차이를 보 이며, 선수 근처 $\left(18 \leq S_{T} \leq 20\right)$ 에서 매우 큰 감소율을 가지고, 평행부 근방인 $2<S_{T} \leq 17$ 에서 감소율은 줄어들었다가, 선미 근처 $0 \leq S_{T} \leq 2$ 에서 감소율이 다시 증가한다.

따라서, 각 $S_{T}$ 에서 총 항력계수 $C_{D}$ 는 선수와 선미 근처에서는 $C_{D P}$ 에 지배적인 영향을 받는, 반면, 평행부에서는 에 지배되어 는 것을 Fig. 4에서 확인할 수가 있다. 하지만, 이와 같이, 선체 를 Station으로만 분할할 경우, 각 Station에서 선저와 수선 사 이의 국소 표면에서의 저항성분들의 정보를 획득할 수는 없다.

이러한 문제를 해결하기 위해, 앞서 Fig. 2에서 정의된 $S_{T}$ 와 $V_{S C}$ 를 두 축으로 하는 2차원 정사각형 평면(SVM)에 선체 국소 저항값들을 나타내면, 선수에서부터 선미까지 또한 선저에서부
터 흘수까지 모든 선체 표면에서의 이러한 값들을 단일 그림에 서 한눈에 파악할 수가 있다.

Fig. 4에서 확인된 바와 같이 $C_{D P}$ 가 양의 최대값을 가지는 $S_{T}=20$ 에서는, 흘수방향으로는 수선 영역인 $V_{S C}$ 에서 최대값을 가 진 후 선저 $\left(S_{C}=0\right)$ 로 갈수록 감소하는 것을 Fig. $5(\mathrm{a})$ 의 등각투상 면에서 관찰할 수가 있다. 특히, $S_{T}=19.5$ 에서 $V_{S C}$ 에 따른 $C_{D P}$ 의 변화를 나타낸 Fig. 5(b)에서 더욱 뚜렷이 확인할 수가 있다. 평 행부에 해 당하는 $4 \leq S_{T} \leq 17$ 에서는 $1 \leq V_{S C} \leq 20$ 의 전 영 역에 걸쳐 거의 ' 0 '값으로 일정한 것을 Fig. $5(\mathrm{a})$ 에서 확인할 수 가 있다. 이는, 평행부 중에서 대표적으로 $S_{T}=10$ 에서 $V_{S C}$ 에 따 른 $C_{D P}$ 의 변화를 보여주는 Fig. $5(\mathrm{~b})$ 를 통해 검증할 수가 있다. $S_{T}$ 에 따른 $C_{D P}$ 의 변화를 나타낸 Fig. 4 에서 확인한 바와 같이, $C_{D P}$ 는 $S_{T}=4$ 를 지나 선미부로 갈수록 급격히 감소하여 $S_{T}=0$ 에서 음의 최대값을 가지는데, 이는 선저부보다 형상의 변화가 큰 설 계흘수 근처에서의 $C_{D P}$ 가 급격히 감소하기 때문인 것을 Fig. 5(b)에서 확인할 수가 있다.

선체 표면의 전단력들의 성분을 사용하여 나타낸 유선들으로 부터 예상되는 바와 같이(Fig. 3), 선수부 전방에서 유체가 선저 로 다소 치우치면서 선체로 유입된 후 선체 표면을 따라 가속 되므로 $C_{D F}$ 는 선수부 $S_{T}=20$ 의 선저 근처인 $V_{S C}$ 에서 가장 큰 값

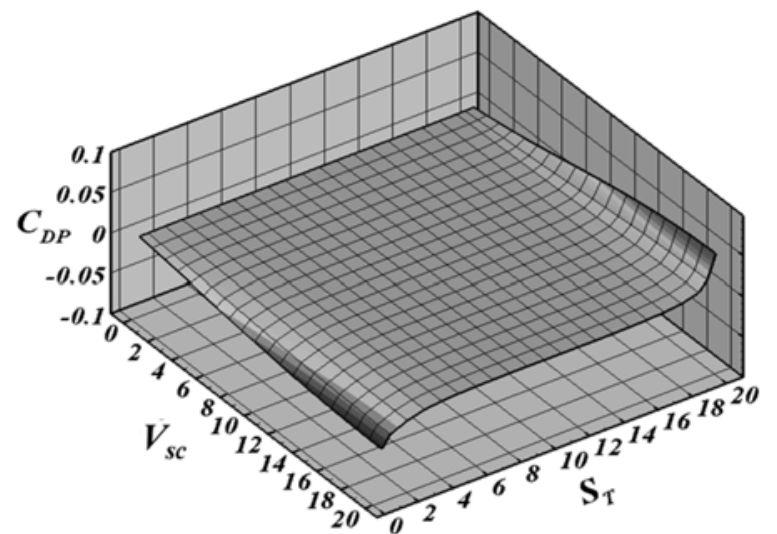

(a)

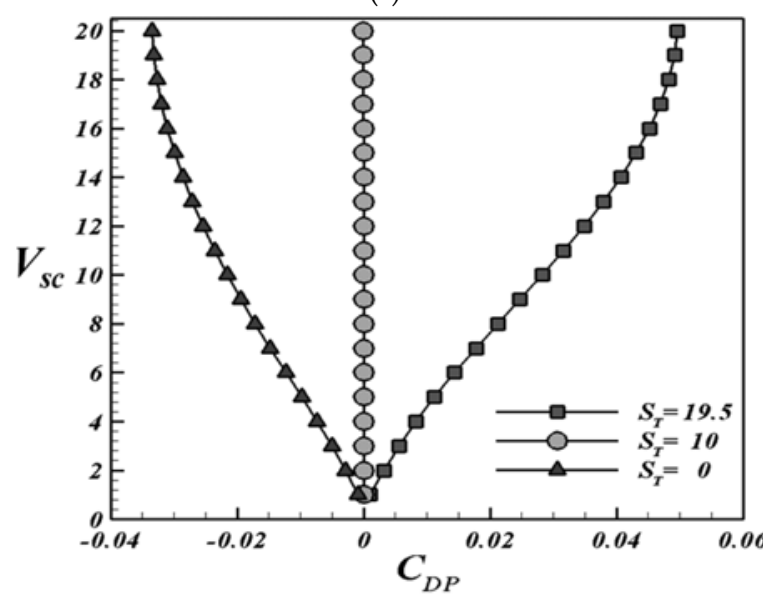

(b)

Fig. 5 (a) Isometric view and (b) the line plot of pressure drag coefficient along the Vertical Section at three different Station of $C_{D F} \mathrm{~S}$ of $19.5,10$ and 0 for Wigley surface 
을 가지고 $V_{S C}$ 가 증가할수록 즉, 수선으로 갈수록, 감소하는 것을 SVM을 사용하여 나타낸 Fig 6(a)에서 확인할 수가 있다. 또한, $S_{T}=19.5$ 에서 $V_{S C}$ 에 따른 $C_{D F}$ 의 변화를 나타낸 Fig. $6(\mathrm{~b})$ 에 서 뚜렷이 관찰할 수가 있다. 선미부 영역 $\left(0 \leq S_{T} \leq 4\right)$ 을 제외 한 모든 Vertical section들에서 Station 에 따른 $C_{D F}$ 의 변화 양 상은 다음과 같이 거의 동일하다. 즉, 선수를 지나면서 $C_{D F}$ 가 감소한 후 평행부에서 거의 일정한 값을 가진다.

선미부 근처에서는, $C_{D F}$ 는 $S_{T}$ 와 $V_{S C}$ 에 의존하며, 특히 $V_{S C}$ 에 더욱 큰 영향을 받는 것을 확인할 수가 있다. 즉, 선저 근처에서 $C_{D F}$ 는 최대값을 가진 후 $V_{S C}$ 가 증가할수록 즉, 수선으로 갈수록 감소하여 흘수근처에서 최소값을 가진다.

\subsection{KVLCC}

Fig. 7는 KVLCC 선체표면에 작용하는 저항분포과 한계유선 을 나타내었다. Fig. 7에 해당하는 선체 길이방향의 각 Station 에 작용하는 압력에 의한 항력계수 $\left(C_{D P}\right)$ 와 마찰에 의한 항력계

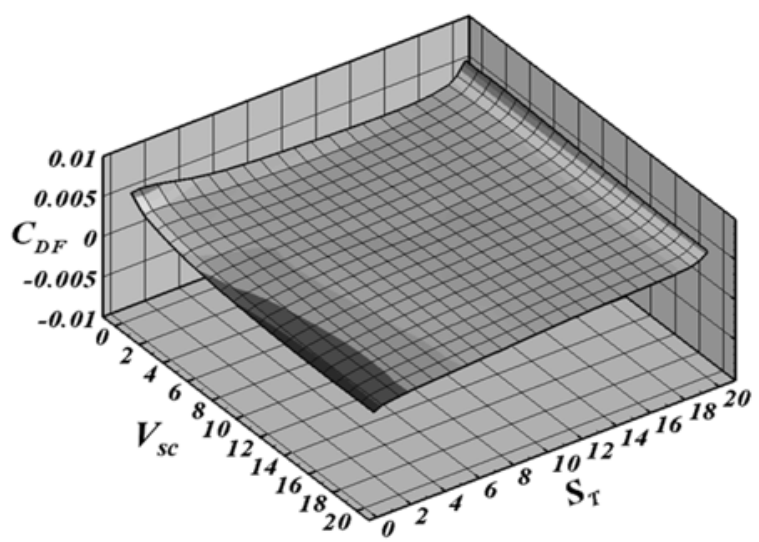

(a)

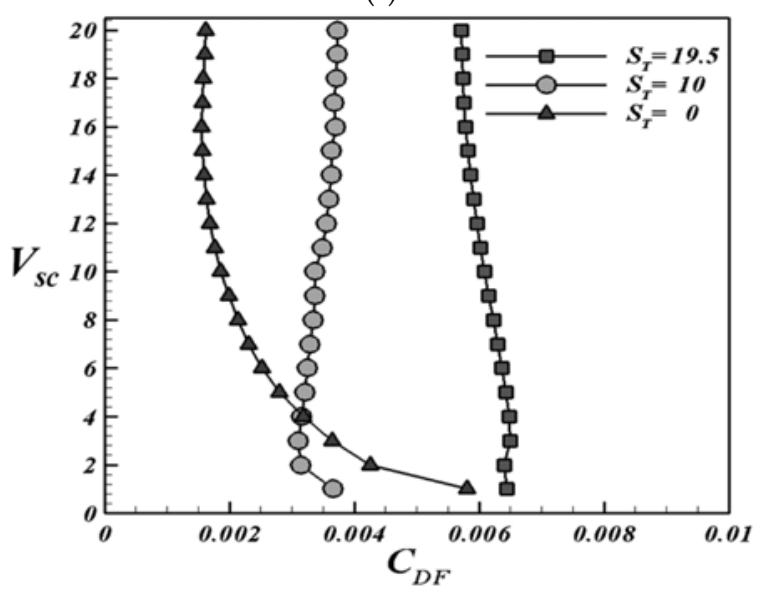

(b)

Fig. 6 (a) Isometric view and (b) the line plot of friction drag coefficient along the Vertical Section at three different Stations of 19.5, 10 and 0 for WIGLEY surface

20 St.

OSt.

Fig. 7 Total pressure \& Wall shear limiting streamlines on the surface of KVLCC

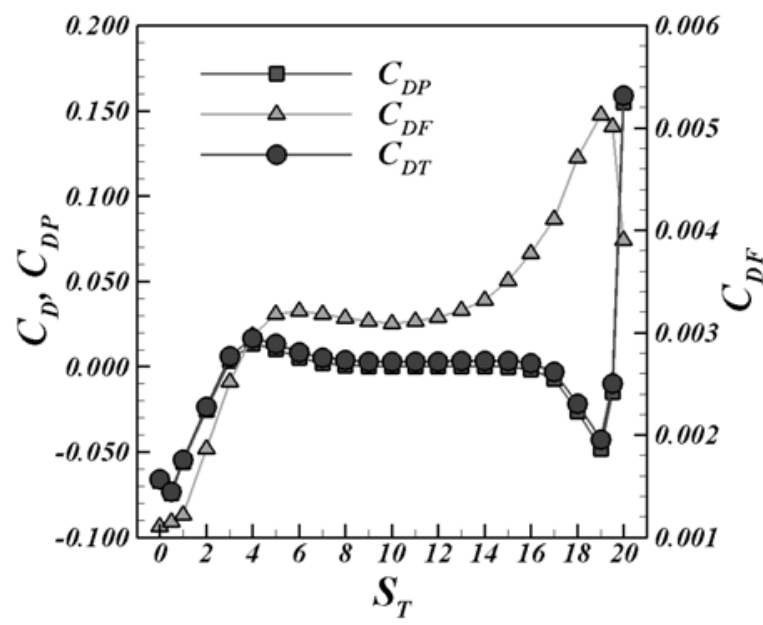

Fig. 8 Drag coefficients as $\mathrm{s}$ function of the station $\left(\mathrm{S}_{\mathrm{T}}\right)$ for KVLCC, where $C_{D}, C_{D P}$, and $C_{D F}$ are total, pressure and friction drag coefficients, respectively

수 $\left(C_{D F}\right)$ 및 이들의 합인 총 항력계수(Total drag coefficient, $\left.C_{D}\right)$ 의 분포를 Fig. 8 에서 보여준다.

KVLCC의 경우, 구상선수에 해당하는 $S_{T}=20$ 은 선형의 특성상 불가피하게 Section을 18 개로 분할하였다. $C_{D P}$ 는 정체점이 존재 하는 구상 선수 부위에 해당하는 $S_{T}=20$ 에 최대값을 가진 후 구 상 선수의 곡면을 따라 유속이 증가하는 영역에서 낮은 압력이 형 성됨으로 $C_{D P}$ 이 급격히 감소하여 음의 값을 $S_{T}=19$ 에서 가진다. $S_{T}=19$ 를 지나면서 $C_{D P}$ 는 다시 증가하여 평행부 영역에서는 거 의 ‘ 0 '값으로 일정하다가, 선미부로 갈수록 다시 급격히 감소하는 경향을 Fig. 8 에서 확인할 수가 있다. $C_{D f}$ 는 정체점을 지나 구상 선수의 곡면을 따라 유속이 급격히 가속되는 영역인 $S_{T}=19$ 에서 최대값을 가진 후 평행부로 갈수록 감소한 하다가 평행부 영역 에 해당하는 Station들에서 일정한 값을 가진 후 선미로 갈수록 급격히 감소한다.

선체 표면에서 $C_{D P}$ 의 변화를 $S V M$ 을 이용한 등각투상면과 선 수, 중앙부 및 선미를 대표하는 $S_{T}$ 들에서 $V_{S C}$ 에 따라 선도를 사 용하여 Fig. 9(a)와 9(b)에 각각 나타내었다. 앞서 Fig. 8에서 언 급된 바와 같이, $C_{D P}$ 가 최대값을 보이는 선수부 $S_{T}=20$ 에서, $C_{D P}$ 는 구상선수의 하단 $\left(V_{S C}=0\right)$ 에서 정체점에 해당되는 상단 $\left(V_{S C}=\right.$ $14)$ 으로 갈수록 증가한 후, 구상선수의 끝단 $\left(V_{S C}=18\right)$ 까지는 큰 변화를 보이지는 않는다. $C_{D P}$ 가 $16 \leq S_{T} \leq 20$ 에서 급격히 감 소 후 다시 증가하는 변화에는(Fig. 8), $V_{S C}$ 가 증가할수록, 즉, 수선에 가까이 있는 $V_{S C}$ 에서의 값들이 더 큰 영향을 미친다. 평 행부에서는, $S_{T}$ 와 $V_{S C}$ 에 따른 $C_{D P}$ 의 변화가 거의 없는 것을 관 찰할 수가 있다. 선미의 복잡한 형상에 기인하여 발생하는 박리 와 빌지 볼텍스(Bilge vortex) 등으로 인해, 특히, 선저와 $V_{S C}=8$ 사이의 영역에서는 $C_{D P}$ 가 $V_{S C}$ 에 따라 저증감하는 하는 것을 Fig. 9(b)에서 확인할 수가 있다.

선수인 $S_{T}=20$ 에서 $C_{D F}$ 는 정체점 부근인 구상 선수의 상단에 서 하단인 선저로 갈수록, 즉 $V_{S C}$ 가 작아질수록 증가하는 것을 Fig. 


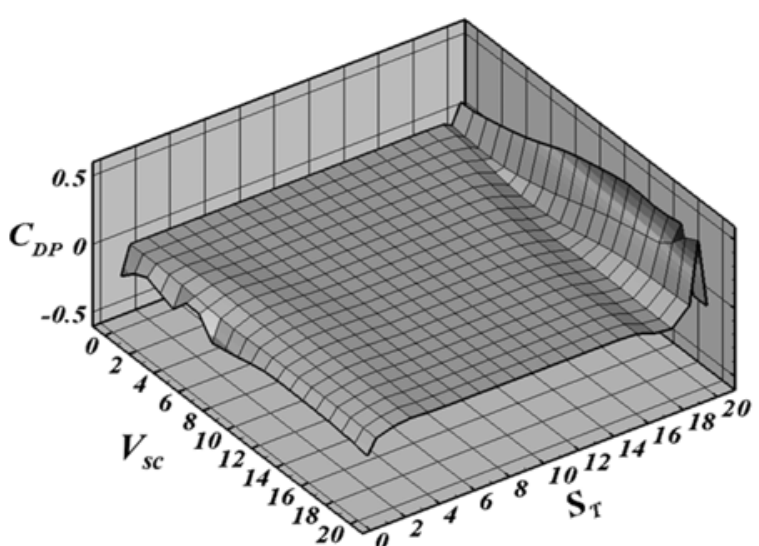

(a)

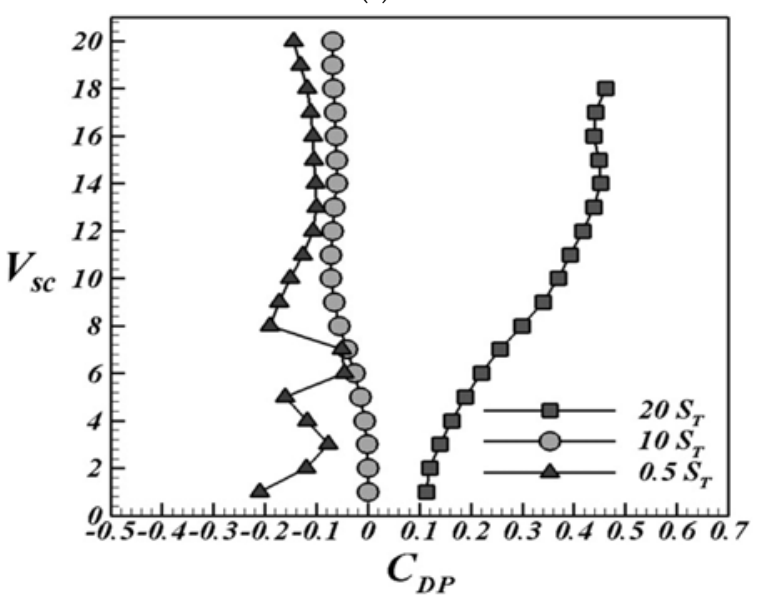

(b)

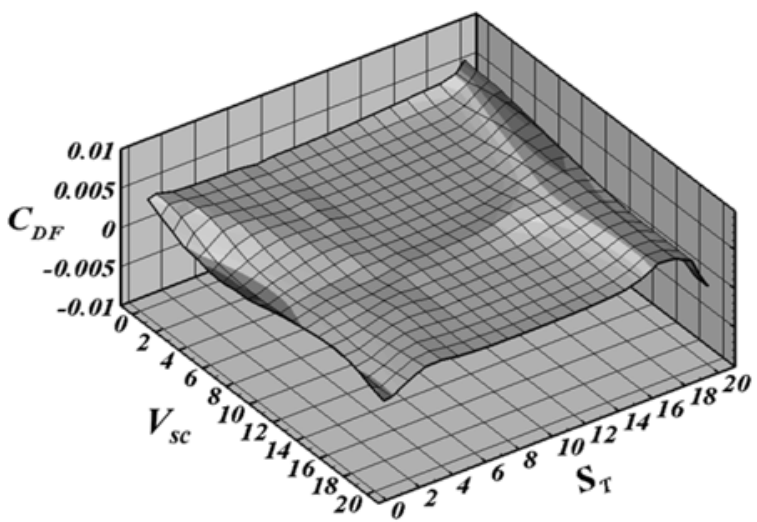

(a)

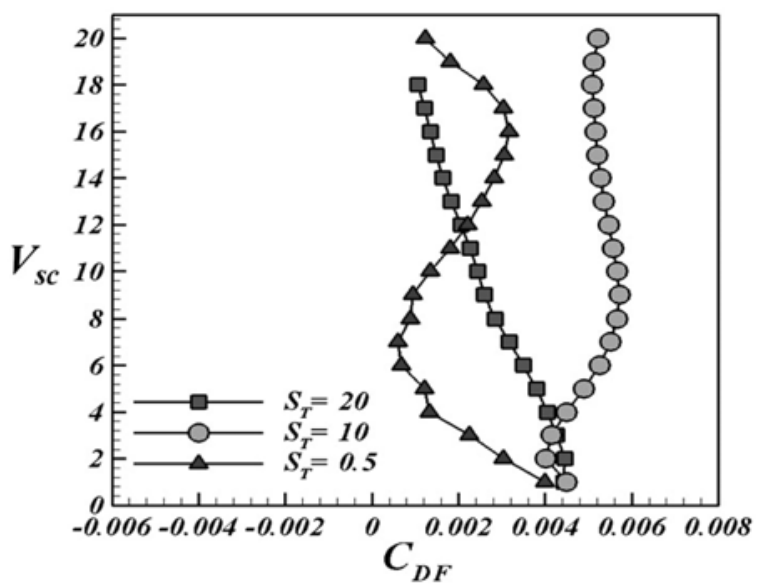

(b)

Fig. 9 (a) Isometric view and (b) the line plot of pressure drag Fig. 10 (a) Isometric view and (b) the line plot of friction drag coefficient along the Vertical Section at three different Stations of 20, 10 and 0.5 for KVLCC surface coefficient along the Vertical Section at three different Stations of 20, 10 and 0.5 for KVLCC surface

10(a) 및 특히 Fig. 10(b)에서 뚜렷이 관찰할 수가 있다. 유체는 구상 선수의 곡면을 따라 전반적으로 선저로 말려 들어가면서 가 속되기 때문에, $C_{D F}$ 의 최대값이 존재하는 $S_{T}=19$ 에서(Fig. 8), 큰 값들은 선저측 Section들 $\left(1 \leq V_{S C}<10\right)$ 에 분포하는 것을 Fig. 10(a)의 등각투상면에서 확인할 수가 있다. 선수 영역을 지나, 평행부 영역에 근접하는 $6 \leq S_{T} \leq 18$ 에서는, $C_{D F}$ 는 빌지 반경 (Bilge radius)에 의해 생성된 곡면부 근처인 $V_{S C} \approx 8$ 를 지나면 서 유속이 증가하므로 여기서 최대값을 가지고 선저와 수면의 양쪽 Section 방향으로 갈수록 작아지는 포물선형 분포를 보인 다. 선미로 갈수록 선저의 프로펠러 스톡 근처 곡면부과 상부 곡면을 따라 유속이 증가하므로, $V_{S C}=1$ 과 $V_{S C}=16$ 에서 각각 국소 피크값들이 발생한다.

\section{5. 결 론}

본 연구에서는, 선체의 저항성능을 보다 체계적이고 표준화된 방법으로 해석할 수 있도록 $\operatorname{Station}\left(S_{T}\right)$ 과 $\operatorname{Section}\left(V_{S C}\right)$ 을 두 축 으로 하는 SVM(Station-vertical section map)에 선체 국소 저항 값을 나타내어 분석하는 새로운 방법을 제시하였다. 선체 표면에
서 국부 저항값 들을 나타낼 경우 단일 그림 상에서 정성적 및 정 량적인 분포를 확인할 수 없었던 단점을 본 연구에서 제시한 SVM 을 도입함으로써 극복할 수가 있으며, 무엇보다, 국소 영 역의 위치를 표준화할 수 있다는 장점이 부각되어진다.

본 연구에서, SVM을 활용하여 두가지 선형인 Wigley와 KVLCC 의 국부 영역에서 저항값들을 범용 프로그램인 Fluent를 사용하여 분석하였다.

Wigley의 경우, $C_{D P}$ 가 양의 최대값을 가지는 선수부에서는, 흘수방향으로는 수선 영역에서 최대값을 가진 후 선저로 갈수 록 감소하는 경향을 보였다. $C_{D P}$ 의 음의 최대값을 가지는 선미 부에서는, 선저부보다 설계흘수 근처에서의 $C_{D P}$ 값들이 지배적 이다. $C_{D F}$ 는 선수부와 선미부에서 동일하게 선저 근처에서 국소 최대값을 가진 후 수선으로 갈수록 감소한다. 평행부에서는 $C_{D P}$ 와 $C_{D F}$ 는 국소영역에 따른 변화가 거의 없다.

$\mathrm{KVLCC}$ 의 경우, $\mathrm{C}_{D P}$ 가 최대값을 보이는 선수부에서는, 구상 선수의 하단에서 상단으로 갈수록 증가한 후, 구상선수의 끝단 까지는 큰 변화를 보이지는 않는다. $C_{D P}$ 가 $18 \leq S_{T} \leq 206$ 에서 급격히 감소 후 다시 증가하는데는, 수선에 가까이 있는 $V_{S C}$ 에서 의 값들이 지배적인 영향을 미친다. 선미에서는, 선저와 $V_{S C}=8$ 
사이의 영역에서는, $C_{D P}$ 가 $V_{S C}$ 에 따라 증감한다. 선수에서, $C_{D F}$ 는 구상 선수의 상단에서 하단인 선저로 갈수록 증가한다. 평행부 영역에서, $C_{D F}$ 는 빌지 반경부에 최대값을 가지고 선저와 수면의 양쪽 Vertical Section 방향으로 갈수록 작아지는 포물선형 분포 를 보인다. 선미부 근처에서는, 선저의 프로펠러 스톡 근처 곡면 부과 상부 곡면을 따라 유속이 증가하므로, $V_{S C}=1$ 과 $V_{S C}=16$ 에서 각각 국소 피크값들이 발생한다.

본 연구에서 제시한 SVM을 사용하여 선형 별 국부 저항값 들 의 데이터베이스화를 통해 새로운 선형 개발 시 유용하게 활용이 가능할 것으로 판단된다. 또한, 에너지 절감형 선형 개발을 위해 도입되는 다양한 유동제어기법들 중에서 국소 영역에서 지배적 인 대상 저항 성분의 파악을 통해 이에 적합한 유동제어기법의 선정에 근거로 사용이 가능할 것이다.

\section{후기}

이 논문은 부산대학교 자유과제 학술연구비(2년)에 의하여 연 구되었음

\section{참 고 문 헌}

Fluent., 2009. Fluent 120 User Guide Manual, Fluent Inc., Levanon
Kim, D.H., Kim, W.J., Van, S.H., 2000. Analysis of the Nonlinear Wave-Making Problem of Practical Hull Forms Using Panel Method. Journal of the Society of Naval Architects of Korea, 37(4), 1-10.

Kim, H.R., Lee, S.J., 1999. Wind Tunnel Study on Flow Characteristics around KRISO 300K VLCC Double-body Model. Journal of the Society of Naval Architects of Korea, 36(3), 15-21.

Lee, S.J., Kim, H.R., Kim, W.J., Van, S.H., 2003. Wind Tunnel Tests on Flow Characteristics of the KRISO 3,600 TEU Containership and 300K VLCC Double-Deck Ship Models. Journal of Ship Research, 47(1), 24-38.

Park, I.R., Kim, J., Van, S.H., 2004. Analysis of Resistance Performance of Modern Commercial Ship Hull using a Level-set Method. Journal of the Society of Naval Architects of Korea, 41(2), 79-89.

Wilson, R.V., Stern, F., Coleman, H., Paterson, E., 2001. Comprehensive Approach to Verification and Validation of CFD Simulations-Part 2: Application for RANS Simulation of a Cargo/Container Ship. ASME Journal of Fluids Engineering, 123, 803-810. 